\title{
O Uso da Ventilação Mecânica Não-Invasiva nos Cuidados Paliativos de Paciente com Sarcoma Torácico Metastático. Relato de Caso*
}

\author{
Noninvasive Mechanical Ventilation in the Palliative Care of a \\ Patient with Metastatic Thoracic Sarcoma. Case Report
}

Mariana Almada Bassani ${ }^{1}$, Ana Beatriz Francioso de Oliveira' ${ }^{1}$, Antônio F. Oliveira Neto ${ }^{2}$, Renata Taize ${ }^{3}$

\section{RESUMO}

JUSTIFICATIVA E OBJETIVOS: Os cuidados paliativos se baseiam na prevenção e alívio do sofrimento, identificando, avaliando e tratando a dor e outros problemas físicos, psicossociais e espirituais. Quadros súbitos de dispnéia são freqüentes em pacientes oncológicos em fase terminal. Nestes casos, a ventilação mecânica não-invasiva pode ser boa opção no manuseio da dispnéia, promovendo conforto e permitindo o contato do paciente com seus familiares. O objetivo deste estudo foi apresentar os benefícios obtidos com a ventilação mecânica não-invasiva no paciente sob cuidados paliativos.

RELATO DO CASO: Paciente com 29 anos, em pósoperatório imediato de Cesareana, admitida na unidade de terapia intensiva (UTI) para tratamento de insuficiência respiratória aguda. À radiografia de tórax visualizava-se massa pulmonar a direita. Após investigação clínica e de imagem foi diagnosticado sarcoma torácico

1. Physiotherapist of the Intensive Care Unit of CAISM - UNICAMP

2. Physician of the Intensive Care Unit of CAISM - UNICAMP

3. Nurse of the Intensive Care Unit of CAISM - UNICAMP

*Received from the Centro de Atenção Integral à Saúde da Mulher, Universidade Estadual de Campinas (CAISM - UNICAMP), Campinas, SP

Submitted on January 30, 2008

Accepted for publication on March 17, 2008

Address for Correspondence

Mariana Almada Bassani

Serviço de Fisioterapia CAISM/ UNICAMP

Rua Alexander Fleming, 1101 - Cidade Universitária

13083-970 Campinas, SP

Phones: (19) 3521-9428 - 3521-9511

E-mail: bassanimariana@hotmail.com

(C)Associação de Medicina Intensiva Brasileira, 2008 metastático em fase avançada, sendo indicadas pela equipe de Oncologia medidas e cuidados paliativos. Para alivio da dispnéia, a equipe multidisciplinar da UTI optou pelo uso de ventilação mecânica não-invasiva (modalidade CPAP + PSV), permitindo a interação da mãe com o bebê e familiares.

CONCLUSÕES: No contexto de cuidados paliativos, a VMNI mostrou-se ser um método capaz de contribuir para o controle da dispnéia provendo conforto e alívio ao paciente.

Unitermos: cuidados paliativos, puerpério, sarcoma, tumor torácico, ventilação mecânica não-invasiva.

\section{SUMMARY}

BACKGROUND AND OBJECTIVES: Palliative care is based on prevention and relief of suffering by identifying, assessing and treating pain and other physical, psychological, social and spiritual problems. Sudden dyspnea is frequently observed in terminal oncologic patients. In these cases, noninvasive ventilation can be an adequate option to control dyspnea by promoting comfort and allowing interaction of the patients with their relatives. The aim of this article was to present the benefits of noninvasive ventilation in the palliative care setting.

CASE REPORT: We report the case of a 29 year old patient, admitted in the intensive care unit (ICU) after cesarean section delivery for clinical treatment of acute respiratory failure. Chest radiograph showed pulmonary mass in the right lung. After clinical and radiological investigation, metastatic thoracic sarcoma was diagnosed and palliative care was introduced. The ICU interdisciplinary team chose to use noninvasive ventilation (mode CPAP + PSV) to relieve dyspnea and discomfort, as well as to allow interaction with her baby and family. 
CONCLUSIONS: Noninvasive ventilation, as a part of palliative management, contributed to dyspnea relief, thus decreasing discomfort.

Key Words: noninvasive mechanical ventilation, palliative care, postpartum, sarcoma, thoracic tumor

\section{INTRODUCTION}

According to the World Health Organization, palliative care is "an approach that improves the quality of life of patients and their relatives when facing problems associated to terminal illness, by means of prevention and relief of suffering, identifying, assessing and treating pain and other physical, psychosocial and spiritual problems"1.

In many patients, the diagnosis of cancer may bring about psychological problems, deteriorating their quality of life. Other commonly observed symptoms are anorexia, dysphagia, dyspnea, weakness and fatigue ${ }^{12}$. When not treatable, all symptoms may be controlled, however it is of paramount importance their early identification by the multiprofessional team. Pharmacological and non-pharmacological resources are used for this control ${ }^{2}$.

Acute respiratory failure (ARF) is one of the main indications for admission in intensive care units (ICU) ${ }^{3,4}$. This complication is often seen by health professionals that deal with oncologic patients at advanced stages of the disease.

Sudden attacks of dyspnea are extremely uncomfortable for the patient and, when due to ARF, may be life threatening. From the clinical point of view, dyspnea may be relieved with the aid of pharmacological (i.e. anxiolytics, opiods and bronchodilators) and non-pharmacological therapeutic armamentarium $^{5}$. Noninvasive techniques such as correct body positioning, breathing exercises and, more recently, noninvasive mechanical ventilation (NIMV) are good examples of non-pharmacological treatments ${ }^{6}$.

According to the II Brazilian Consensus in Mechanical Ventilation, noninvasive ventilatory support must be part of the initial approach the to treatment of acute and chronic respiratory failure aggravated by several etiologies ${ }^{7}$. The main objective of using NIMV is to improve gas exchange and reduce ventilatory work ${ }^{8}$.

The reversible nature of the disease must be always taken into account when using ventilatory assistance in palliative care. Therefore, when used for palliative purposes, the main goal of this intervention is to re- duce discomfort, reducing human suffering. Perhaps the major advantage of using NIMV as ventilatory support is the possibility to provide relief and comfort to the patient by avoiding endotracheal intubation and preserving the individual's right to manifest and express his/her will and cravings ${ }^{5}$.

Palliative care is based upon six principles: to value life and consider death a natural process; neither to accelerate death nor to prolong life; to promote relief of pain and other symptoms; to integrate psychosocial and spiritual aspects; to provide support to the family during the illness and time of mourning ${ }^{1}$.

The aim of this study was to report the case of a patient with neoplastic disease at an advanced stage, who was benefited by the use of NIMV as a palliative care intervention.

\section{CASE REPORT}

We report the case of a 29 years old patient, caucasian, pregnant (G2P1AO) with 30 weeks +5 days of gestational age with a pathological history of resection of a soft tissue sarcoma in the right thigh in 2004. When admitted at the emergency ward of the Centro de Atenção Integral à Saúde da Mulher (CAISM) of the Universidade Estadual de Campinas (UNICAMP), she presented acute respiratory failure (ARF) of non-defined etiology, lethargy and premature labor. Fetal evaluation revealed acute fetal suffering, and immediate resolution of pregnancy was taken by the obstetric team. The patient was referred to the obstetric center for a cesarean section delivery under general anesthesia. Due to the undefined condition of ARF upon admission at the emergency ward and altered respiratory examination findings, the anesthesia team requested admission to the ICU for monitoring and ventilatory weaning. The preterm female newborn, small for gestational age $(1,300 \mathrm{~g})$, was referred to the neonatal ICU.

At physical examination upon admission to the ICU, the patient maintained sedation of 5 on Ramsay sedation scale, was normotensive with regular heart rate. Cardiovascular examination findings were normal, and lower limbs presented symmetric pulse and no edema. At pulmonary auscultation, there was initially a decreased vesicular murmur at the right upper apex (96\% $\mathrm{O}_{2}$ saturation). Arterial blood gases and chest radiograph were requested. Imaging evaluation revealed extensive opacity of undefined etiology in the right upper field (Figure 1). 


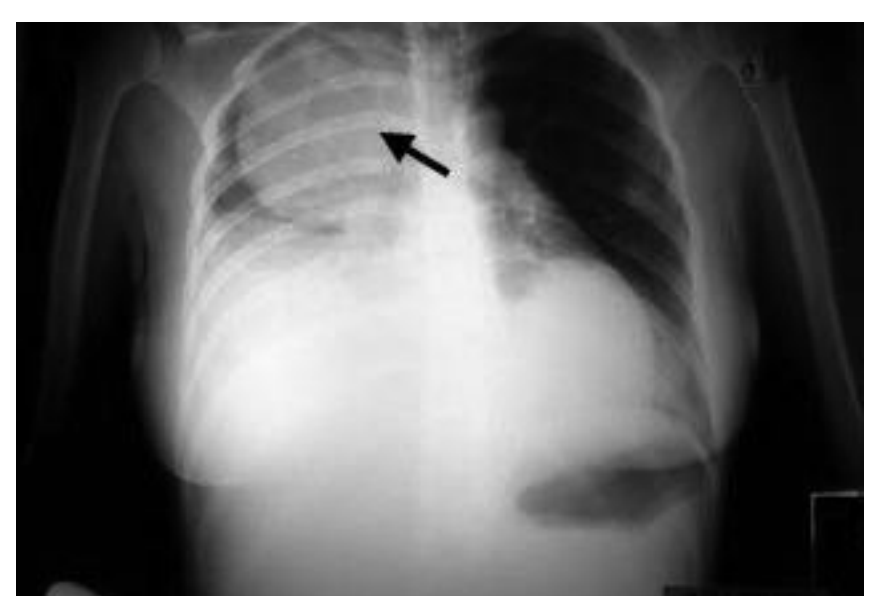

Figure 1 - Chest Radiograph of Lung Metastasis

Considering the hemodynamic stability and adequate ventilatory parameters, tracheal extubation was elected and performed without intercurrences. In accordance with the clinical and radiographic parameters and history of soft tissue sarcoma, the ICU team requested an evaluation by the team of Oncology and Thoracic Surgery.

There was worsening of the overall condition on the first day of admission, with paleness, moderate dyspnea $(R R=36)$, throbbing of the nostrils, hemoptysis and lymphedema of the upper right limb and neck soft tissue on the right side. Pulmonary auscultation disclosed pronounced decrease of vesicular murmur in the right hemithorax, with presence of crackles at lung bases. Patient continued on oxygen therapy with a facial mask $(10 \mathrm{~L} / \mathrm{min})$ and $96 \%$ saturation at pulse oximetry.

The relevant laboratory exams at admission and second day in the ICU are presented in table 1. Chest tomography and lung biopsy were performed (Figure 2) on the second day of admission. The patient was frightened, anguished and concerned with her daughters, mainly the newborn (NB). She cried frequently and requested the constant presence of her husband and mother, manifesting an intense desire to hold her newborn daughter and breastfeed her.

Table 1 - Laboratory Exams on Admission to the ICU and on the Second Day of ICU Stay

\begin{tabular}{lcc}
\hline Exams & Admission in ICU & Second day in ICU * \\
\hline Hemoglobin & 15.7 & 9.3 \\
Hematocrit & 27.2 & 328.9 \\
Leukocytes & - & 11.190 \\
Platelets & 633.000 & 571.000 \\
$\mathrm{pH}$ & 7.44 & 7.41 \\
$\mathrm{PaO}_{2}$ & 108 & 110 \\
$\mathrm{PaCO}_{2}$ & 26 & 39 \\
$\mathrm{HCO}_{3}$ & 18 & 23 \\
Base excess $_{\mathrm{O}_{2} \text { Saturation }}$ & -5 & -1 \\
\hline
\end{tabular}

*After NIMV started

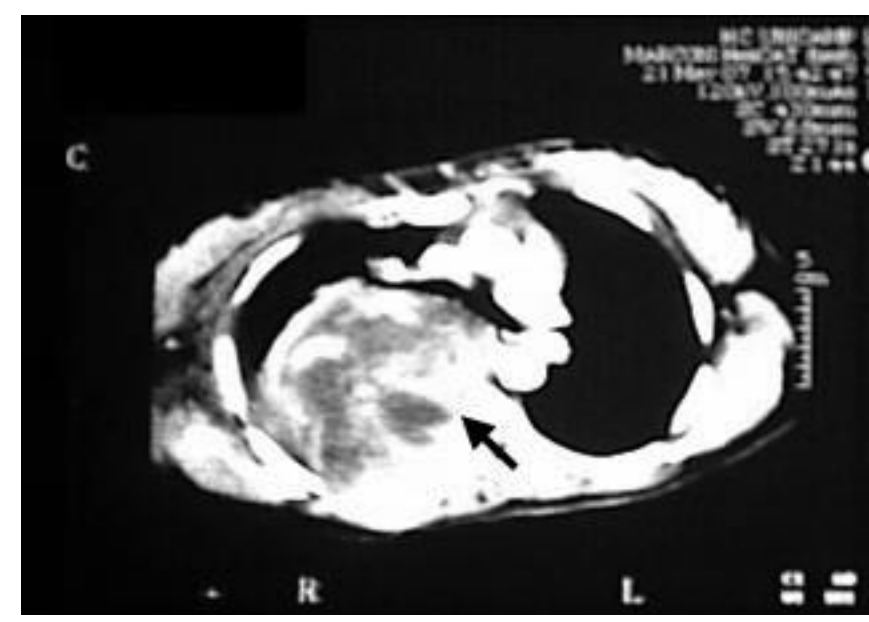

Figure 2 - Computerized Tomography of the Lung Metastasis

After clinical, radiological and anatomopathological evaluation (fusocellular sarcoma of the thorax), the Oncology and Thoracic Surgery teams confirmed the advanced stage of the oncologic disease, for which no curative therapy was available, and, therefore, support and palliative measures were indicated.

The proposed management of life support and transference to the palliative care ward were discussed, whereupon the interdisciplinary team decided that the patient should receive palliative care at the ICU. This would, at least temporarily, permit maintenance of consciousness and the capacity of the patient to communicate so as to express and receive affection.

For control of dyspnea, in addition to use of opiods, the multidisciplinary team decided for noninvasive mechanical ventilation (NIMV) by means of the Inter 5 respirator from Intermed, via a face mask. The ventilatory setting was continuous positive airway pressure mode with pressure-support (CPAP + PSV), with a peak inspiratory pressure (PIP) of 20 to $25 \mathrm{cmH}_{2} \mathrm{O}$, positive expiratory end pressure (PEEP) of $10 \mathrm{cmH}_{2} \mathrm{O}$ and fraction of inspired oxygen $\left(\mathrm{FiO}_{2}\right)$ from $30 \%$ to $80 \%$. This was performed from one to three times a day with a mean duration of 40 minutes, as needed. During her stay, the patient received visits without restrictions from family members and the NB and, according to her wish, breastfed her daughter every day. On the sixth day of hospital stay, the patient evolved with worsening of the breathing condition and lowering in the level of consciousness. With the same intention to provide comfort and reduce patient and family suffering, the patient was sedated, submitted 
to tracheal intubation and invasive ventilatory support. A few hours later, the patient died.

\section{DISCUSSION}

A cancer patient is more prone to develop respiratory failure by infections, ventilatory/perfusion mismatch secondary to athelectasis, shunt or congestion of the pulmonary veins, and also by decrease of the airway caliber due to extrinsic or intrinsic compression ${ }^{3}$. Dyspnea is one of the most frequent symptoms in patients with advanced cancer (70\%). However, most oncologic patients with acute respiratory failure are not admitted at an ICU ${ }^{3,9}$ unless they present a malignancy with a potential for cure and/or control, and especially when the condition leading to admission is reversible ${ }^{9,10}$. Pinheiro and Brito stressed that the main prognostic factor for oncologic patients at an ICU is the occurrence of acute organic dysfunctions, mainly respiratory, when the patient requires invasive mechanical ventilation ${ }^{11}$. For Azoulay and Afessa, patients with terminal diseases, bedridden or with complications related to bone marrow transplant, as well as those who are strong candidates for palliative care should not be admitted at the ICU ${ }^{12}$. However, Thiery et al. stress that a patient with recent diagnosis of malignancy must be admitted to these units whenever necessary, otherwise a careful triage is advisable ${ }^{9}$. Thiery et al. also suggest that the use of invasive mechanical ventilation must be carefully evaluated in cancer patients for whom there is no curative proposal ${ }^{9}$.

The main purpose of palliative care is to improve quality of life of the patients without a curative therapeutic proposal, achieving relief of suffering through early diagnosis, management of pain and reduction of discomfort ${ }^{6}$. NIMV is a form of ventilatory support by positive pressure, generally carried out with a mask, with the purpose of improving gas exchange and reducing ventilatory work $^{3,8}$. In some cases, it avoids endotracheal intubation and its related complications, such as infection of the upper and lower airways that are known to increase mortality $3,8,13$.

Information regarding the stage and therapeutic oncological management is often not available at the time of admission. Therefore, noninvasive therapeutic interventions, such as NIMV, might be useful ventilatory resources $^{12 .}$

Still in the context of palliative care, Meduri et al. showed that, in terminal patients with chronic pulmonary obstructive disease, NIMV is an interesting alternative even when intubation is ethically or clinically questionable, due to improvement of respiratory rate and blood gas $^{14}$. Nava et al. observed in a prospective multicentric study that most European hospitals with palliative care services use NIMV as the main ventilatory support in the case of patients with "do-not-intubate" orders ${ }^{15}$. Nevertheless, some authors believe that NIMV is a way to prolong life of a patient with no curative therapeutic proposal ${ }^{13}$.

Use of NIMV in the clinical case here reported aimed at reducing ventilatory effort, relieving dyspnea. It is noteworthy that the use of NIMV was not intended to prolong life of the patient. It was used to reduce dyspnea, permitting interaction with her family, mainly with her NB baby.

The noninvasive ventilation mode used was CPAP + PSV. The use of PEEP is pertinent for alveolar recruitment and stabilization ${ }^{16}$. In the reported case, alveolar recruitment was impossible due to compression of the lung tissue by the tumor. However, we suppose that PEEP may have helped to stabilize the partially collapsed alveoli in the adjacent areas.

According to the II Brazilian Consensus in Mechanical Ventilation, $\mathrm{FiO}_{2}$ values above $60 \%$ indicate failure of $\mathrm{NIMV}^{7}$. Nevertheless, for the purpose of maintaining the patient conscious and able to express and feel emotions, the multidisciplinary team elected the use of NIMV, even with the requirement for high values of $\mathrm{FiO}_{2}(80 \%)$. The team's major concern with the possibility of verbal communication was because the patient was the mother of a newborn baby and a 5 year old daughter. Furthermore, emotional aspects, such as fear and distress, also influenced the choice. The fact that she could stay with her baby and her oldest daughter calmed the patient and her family.

On her last day of life, NIMV was no longer sufficient to reduce dyspnea, and the patient was tired and lethargic. With the continued purpose to relieve suffering and offer comfort to the patient and family, the intensive care physician chose sedation, endotracheal intubation and invasive ventilatory support. Once on invasive mechanical ventilation, minimum parameters of $\mathrm{FIO}_{2}$ and PEEP were maintained to reach a SatO $\mathrm{S}_{2}>90 \%$. Anxiolythics and analgesics were administered (benzodiazepines and opiods) aiming at sedation of 3 to 4 on the Ramsay sedation scale. No form of therapy that infringes the principles of palliative care was adopted. After the patient's death, her husband expressed great satisfaction with the care his wife had received, mainly regarding the visits of the newborn. Nine months after 
his wife's death, he told the team that, in his opinion, his wife had been very well cared for.

Evidence for use of NIMV in terminal patients, essentially in the postpartum, is scarce. We believe that, in the palliative care setting, NIMV has proven to be adequate for control of dyspnea and patient comfort, providing a better quality of life at the end of life.

\section{ACKNOWLEDGMENTS}

We thank the Physiotherapy Service of CAISM/UNICAMP and the staff of the Adult Intensive Care Unit of CAISM. The family gave written consent for publication of this article.

\section{REFERENCES}

01. da Silva RC, Hortale VA - Palliative care in cancer: elements for debating the guidelines. Cad Saude Pública 2006;22:2055-2066.

02. Patrick DL, Ferketich SL, Frame PS, et al. National Institutes of Health State-of-the-Science Conference Statement: Symptom Management in Cancer: Pain, Depression, and Fatigue, July 15-17, 2002. J Natl Cancer Inst, 2003;95:1110-1117.

03. Nava S, Cuomo AM - Acute respiratory failure in the cancer patient: the role of non-invasive mechanical ventilation. Crit Rev Oncol Hematol, 2004;51:91-103.
04. Divatia JV - Critical care for cancer patients. Indian J Crit Care Med, 2007;11:1-3.

05. Karwa M, Chandra A, Mirza A - Palliative Care and Chronic Obstructive Lung Disease, em: Blank AE, O'Mahony, Selwyn A - Choices in Palliative Care: Issues in Health Care Delivery. New York, Springer Science + Business Media, 2007.

06. Marcucci FCl - O papel da fisioterapia nos cuidados paliativos a pacientes com câncer. Rev Bras Cancerol, 2005;51:67-77.

07. Suporte ventilatório não-invasivo com pressão positiva e suporte ventilatório mecânico domiciliar. In: II Consenso de Ventilação Mecânica. J Bras Pneumol, 2000;26:(Suppl2):S60- S62.

08. III Consenso de Ventilação Mecânica - J Bras Pneumol, 2007;33:(Suppl2):S92-S105.

09. Thiery G, Darmon M, Azoulay E - Deciding intensive care unit- admission for critically ill cancer patients. Indian J Crit Care Med, 2007;11:12-18.

10. Soares M, Salluh JIF - Prognostic factors in cancer patients in the intensive care unit. Indian J Crit Care Med, 2007;11:19-24.

11. Pinheiro CTS, Brito L - Prognóstico de pacientes oncológicos em uma unidade de tratamento intensivo. Rev Bras Ter Intensiva, 2001;13:99-102.

12. Azoulay E, Afessa B - The intensive care support of patients with malig nancy: do everything that can be done. Intensive Care Med, 2006;32:3-5.

13. Curtis JR, Cook DJ, Sinuff T, et al. Noninvasive positive pressure ventilation in critical and palliative care settings: understanding the goals of therapy. Crit Care Med, 2007;35:932-939.

14. Meduri GU, Fox RC, Abou-Shala N, et al. Noninvasive mechanical ventilation via face mask in patients with acute respiratory failure who refused endotracheal intubation. Crit Care Med, 1994;22:1584-1590.

15. Nava S, Sturani C, Hartl S, et al. End-of-life decision-making in respiratory intermediate care units: a European survey. Eur Respir J, 2007;30:156-164.

16. PEEP (pressão positiva ao final da expiração), em: II Consenso de Ventilação Mecânica. J Bras Pneumol, 2000;26:(Suppl2):S11-S12. 